DOI: http://doi.org/10.4038/tjata.v1i2.44

\title{
Promoting Peace Through Tourism
}

\section{Erangi Wijayawickrama}

Department of Philosophy, Faculty of Social Sciences, University of Kelaniya

\author{
erangiwijayawickrama@gmail.com
}

\begin{abstract}
This paper discusses the relationship between peace and tourism and the way how tourism leads to peace. Tourism doesn't have a direct link with peace. But in several ways, tourism open paths to way for peace. Tourism should be designed and conducted properly to proceed and to maintain peace in society. Tourism in itself is a complex phenomenon. There are many benefits of the tourism industry. Of them implementing peace can be identified as one benefit. Peace means the absence of violence. In society, we can identify the structural violence which happens due to a lack of economic, social, political imbalance in many ways. The main reason for the structural violence is poverty. By implementing the tourism industry in society, it can be used to eliminate poverty by increasing economic development. Then indirectly Tourism has made the path for peace. Tourism is an extremely complex phenomenon through which identities and worldviews are continuously being represented, consumed, reconfirmed, negotiated and modified. This article describes separately peace, tourism and the relationship between tourism and peace. Tourism means a trip or a visit to an unknown place or a new place from the home place. By that tourists will meet different cultural people, and will understand the diversity of cultures as well as will learn the importance of respecting the diversity. This phenomenon also helps to share love and harmony with culturally different people. It will be an initiating point to begin peace in the world.
\end{abstract}

Keywords - Peace, Tourism, Structural violence, Economic Development 


\section{Introduction}

There is a complex relationship between tourism and peace. Rather than trying to defend an over-simplified concept of 'tourism as an agent for peace' or simply 'tourism as an agent for dispute, inequality, and exploitation of the poor' we should first try and understand before making any judgment. It is not that tourism is 'an agent for peace' but instead are pleading for 'peace-sensitive tourism', a less ambitious expression than the 'peace-through-tourism' idea. The International Institute for Peace through Tourism (IIPT) was founded in 1986, dedicated to 'fostering tourism initiatives which contribute to international understanding and cooperation.' The IIPT has sponsored several conferences and seminars, addressed and attended by representatives from the tourism industry, governments, and environmental and human rights organizations. These have resulted in a range of initiatives concerned with codes of ethics, sustainable tourism and alleviation of poverty.

"Travel has become one of the great forces for peace and understanding in our time. As people move throughout the world and learn to know each other, to understand each other's customs and to appreciate the qualities of individuals of each nation, we are building a level of international understanding which can sharply improve the atmosphere for world peace."

John F. Kennedy

Almost all the people seem to agree that "peace is an essential precondition for travel and tourism and all aspects of human growth and development." (Amman Declaration on Peace through Tourism). This article aims to analyze the relationship between peace and tourism and to describe how tourism can lead to peace. The current situation of tourism shows that it is important for all the actors of tourism to promote tourism sustainably not only for the principled aim of love for humanity of human beings and nature but also for their pleasure and sustainable development. If each actor plays its role, tourism can gradually lead to peace. This article examines 
separately how can tourism lead to sustainable peace in society, with examine several current examples.

\section{Objectives of The Study}

The main objective of this research was to determine, how tourism can be used as a tool to promote peace. And the sub-objectives of the research were to identify the relationship between tourism and peace and also to identify how tourism can be used to eliminate structural violence from the society.

\section{Methodology}

Qualitative data were used to conduct this research and was collected from books, magazines, previous researches and computer sources. Mainly the conceptual analysis was conducted within this research to define and analyze the collected data.

\section{Discussion}

This study discusses the main areas according to the objective of the study as mentioned below.

- Defining Peace

- Defining Tourism

- How Peace interconnected with Tourism

- Effect of Tourism in eliminating structural violence

\section{Defining Peace}

Peace is a process; a many-sided, never-ending struggle against violence. Both those who accept the need for coercive force, including violence and those who take a nonviolent stance, and the many others with views in between, would say that they want peace. Many people understand peace to be absence of war. The absence of war is often described as negative peace and is contrasted with positive peace, which encompasses all aspects of a good society. 
Peace is often considered as an opposite word of war as symbolized by the famous Russian novel War and Peace written by Leo Tolstoy. Kenneth Boulding defined stable peace as "a situation in which the probability of war is so small that it does not enter into the calculations of any of the people involved (Boulding 1978). Nations are making every effort to keep the peace by defending their society from the threat of war, violence and terrorism through the building of armaments and armies. In this context, peace is defined negatively as the "absence of war."

The pursuit of peace, therefore, is not directed merely to the elimination of war. To continue the analogy with health, if these are regarded as contributors to violence (illness), then tourism offers a range of therapies through which they may be treated. However, this narrow characterization, which does not consider the fundamental causes of conflicts or sustainability of peace globally, is not a sufficient condition for peace. Although implicitly assumed in the often-used metaphor of 'building' peace, peace does not necessarily have to be something humankind might achieve someday.

\section{Defining Tourism}

Tourism is nowadays viewed as a vibrant, dynamic industry. Tourism is the practice of travelling for pleasure; and the business of providing tours and services for tourists. Tourism is believed by many people to be "a service industry that takes care of visitors when they are away from home" (Lowry,1994). Tourism is a social phenomenon. Economic elements are the lubricant of better socio-cultural interactions and human-nature relations, and political elements come under the influence of the changes of socio-cultural situation. Therefore, tourism should be examined in this context. The purposes of tourists are business, study, pleasure, leisure or visiting families and relatives. They move voluntarily from one place to another. There are interactions between tourists, business suppliers, host governments and host communities and/or contacts between humans and Mother Nature. Although the nature of tourism might vary from person to person, the common denominator is that all of them seek something new, exotic, and different from what they see in their daily lives. 
Tourism has both negative and positive impacts on the globalized world. Of them, tourisms have lots of positive impacts. Tourism has the potential to promote cultural exchange as a means of breaking down the barriers between peoples of different nations. It also gives tourists good opportunities to develop environmental awareness and makes them think about what to do to ensure the sustainable prosperity of the Earth.

There are four main positive economic impacts of tourism. First, tourism increases foreign exchange earnings and contributes to government revenues. Second, host residents are benefited from the facilities and services developed for tourism. Third, tourism leads to significant employment creation. Fourth, tourism facilitates the process of poverty alleviation and income distribution between countries, thereby contributing to a more balanced development of the world economies. Also, tourism can revaluate and preserve local culture and traditions. More and more people are becoming familiar with the local culture and know the advantages and problems of that culture. Tourism can be a driving force for giving locals a motivation for boosting the development and maintaining their pride. Important benefit of tourism is can be a means of reducing tension and promoting harmonious relations. It brings people into contact with each other and provides cultural exchange between hosts and guests.

\section{How Peace Interconnected with Tourism}

According to the definitions of tourism and peace, it can be identified that tourism works for suspension of war, elimination of structural violence and action for the improvement of global issues. Tourism has its role to operate as a helping hand to enforce the track one diplomacy. It is sometimes utilized as a method of reducing political tension, achieving reconciliation in divided societies, preventing moving back into a state of war. And in another case, tourism promotes mutual understanding, business opportunities and people-to-people contact between the peoples of conflicting countries, which create an opening for the initiation of negotiations toward peaceful relationships. "Tourism operates at the most basic level of track two diplomacies by spreading information about the personalities, beliefs, aspirations, 
perspective, culture and politics of the citizens of one county to the citizens of another (Amore, 1988). The contact model of social psychology, which supposes that "contact among individuals from diverse groups enhances understanding and acceptance among the interacting parties and therefore reduce intergroup prejudice (Pizam, Fleischer, Mansfeld 2002). The sharing of common goals, voluntary and intimate contact and the absence of negative personality structures are integral in the development of positive attitudes for tourists. It must be stressed that this positive attitude change is amongst tourists and has not been evaluated for the other parties involved in the contact situation; the host community. Poorly developed tourism has a distinct ability to deliver positive outcomes to tourists at the expense of the host community. Attitude change is an important factor but it cannot be taken in isolation if tourism is to be regarded as a genuine force for peace. It must work in conjunction with other strategies to alleviate the recognized negative impacts associated with tourism. Tourism might generate all the goodwill in the world but it will be of little value in developing peace if poverty, pollution and social domination remain rampant. When understanding how positive attitude change occurs is integral in developing experiences that assist tourism to become a force for peace.

Tourism, like peace, can be broken easily. There are many examples of how a political crisis, security threats, financial collapse, natural disaster or military conflict can seriously damage and even destroy tourism in a particular region, country or destination. Peace, as we all know, is equally weak, depending as it does on human relations. Prejudice, misconception and intolerance are root causes of the destruction of peace. That is why tourism is an associate of peace. Tourism establishes contact between visitor and host, between different cultures, between peoples and places. How can anyone feel enmity for someone who has received him and made him feel safe and welcome? To travel, cross borders, visit new places and encounter different cultures, is a learning process that leaves the visitor wiser and more tolerant. By breaking down the divisions between people, tourism contributes to a better understanding between the peoples of the world. It opens the eyes of people so that we can see one another as we are equal human beings, each person with his or her own unique culture, values, history, traditions and customs. 
Tourism in various forms can play a role through its ability to bring people together. Tourism does have a role in conflict resolution, confidence building and reconciliation, but not in an isolated way. It is too heavily shaped by other cultural or political dimensions in any given society. Thus, peace politics and culture also have an impact on the way tourism is conceived and practised.

\section{Effect of Tourism in Eliminating Structural Violence}

Structural violence is the result of the widespread social, political, and economic inequality that exists within a local area as well as in the global space of international relations. Structural violence includes the systems of economic exploitation, political repression and cultural alienation, which deny some people the necessities of life, basic human rights, representation, security, freedom of expression. Poverty is the most typical and explicit form of economic and political structural violence. Understanding sources and patterns of poverty is a significant key to eliminating structural violence. In most cases especially in less developed countries, foreign and private sector interests seize the initiative with tourism development.

Tourism is one of the few sectors in which governments have a strong role in planning, licensing, regulation and marketing, providing an invaluable entry point to influencing the sector at the national level. A community involved in the planning and implementation of tourism has a more positive attitude, is more supportive and has a better chance to make a profit from tourism. One of the core elements of eliminating structural violence is community development, which enables locals to make decisions that consider the long-term economy, ecology and equity of all communities.

Tourism initiate economic development. Poverty can be eliminated through economic development. Therefore, as it doesn't seem a direct link between peace and tourism, it is clear that an increasing economy will affect reducing poverty. As structural violence is highly based on economic conflicts and issues, the Tourism industry can be used as the best tool in increasing the country's economic status. 
Kelly, in his 'Peace through Tourism Implementation Guide' names potential areas of action. He lists four broad and overlapping areas in which he hopes that their implementation might have the required effect. He outlines (Kelly 2012)

- "Intergroup contact

- Ethical concerns (respect for the environment and human rights)

- Positive impact of tourism on negative elements of globalization (poverty eradication)

- Awareness raising among suppliers and consumers by codes of conduct, peace parks and tourism education."

There are some other linkages between tourism, as a cultural and social activity supported by a multi-layered industry, and peace, as a process that aims to reduce human violence targeted at other humans and nature through peaceful means (Galtung 2011). Base these linkages on dimensions that stem from the tourism impact but are also an integral part of peace processes. Thus, we distinguish educational, economic, and environmental dimensions as well as the dimension of conflict resolution and reconciliation issues.

\section{Conclusion}

Tourism is not a generator of peace, but a beneficiary of it. Therefore, the development of responsible tourism is necessary for this and has a chance of success only because it creates hope through discussions for the people who live in these difficult situations. Potential motives for responsible tourists visiting these regions of conflict could be 'interest in the country', 'support and solidarity', 'a desire to understand the real cause of the conflict' generating new ideas and participating in projects that benefit the country in terms of education, health and empowerment of the youth.

This article has attempted to contribute to the debate on the role of tourism as a force for peace and the creation of hope and international understanding by investigating the role that tourism, and in particular, tourism plays in fostering relations between 
divided nations. The mere presence of responsible tourists already contributes to this much-needed principle of hope.

The aim of 'peace through tourism' is to reduce, if not eliminate, the conditions which lead to a perception that violence is necessary. It stems from a belief that the circumstances in which resorting to violence appears to be appropriate can be ameliorated or avoided, and that tourism is one channel for bringing this about. It is also argued in this book that peace through tourism is more likely to be achieved if it is pursued by both governments and individuals. The goal of Peace through Tourism is to move tourism from practices marked by insensitivity, inequity and short-term maximization to a broader view that recognizes long-term obligations to travellers, destination and wider communities, and succeeding generations. At the very least, providers and consumers of travel experiences could adopt the principle, 'Do no harm.'

However, stakeholders in these destinations should be involved in a dialogue in which spaces are created, where responsible tourists in agreement with various stakeholders involved can generate new ideas and projects that are needed for the further creation of hope and peace-building.

\section{References}

Ap, J. \& Var, T. (1998). Tourism and world peace. In W. F. Theobald (Ed.), Global tourism, Boston, USA: Butterworth-Heinemann

Barash, P.(ed.), Approaches to Peace: A Reader in Peace Studies (Oxford, Oxford University Press, 2000)

Boulding, K. (1978), Stable Peace (Austin: University of Texas Press, 1978)

Brown F (1989) Is tourism really a peacemaker? TourismManagement 10(4)

D’Amore, L.(1988b), 'Tourism - The World's Peace Industry', Journal of Travel Research, Vol.27, No.1 
Etter, D. (2007). Situational conditions of attitude change within tourism settings: understanding the mechanics of peace through tourism.

Galtung, Johan. 2011. „Konfliktformationen in der Welt von Morgen. “In State-of-Peace Konferenz. Ein Rückblick auf 25 Jahre Friedens- und Konfliktforschung, edited by Bert, Preiss, and Ronald Tuschl, Wien/Berlin: LIT Verlag.

Kelly, Ian. 2012. "Peace Through Tourism. An Implementation Guide.”The Journal of Tourism and Peace Research

Khamouna, M. and Zeiger, J.B., 'Peace through Tourism', Parks and Recreation (September, 1995), pp.80-86.

Litvin SW (1998) Tourism: the world's peace industry? Journal of Travel Research 37(1)

Pedersen, S. B. (2020). A passport to peace? Modern tourism and internationalist idealism. European Review, 1-14. Pizam, A., Fleischer, A. and Mansfeld, Y. (2002), 'Tourism and Social Change: The case of Israeli Ecotourists Visiting Jordan', Journal of Travel Research, Vol.41

Salazar, N. B. (2006). Building a'Culture of Peace'through Tourism: Reflexive and analytical notes and queries. universitas humanística, (62), 319-336. 